\title{
Antidiabetic effect of Coccinia grandis (L.) Voigt (Cucurbitales: Cucurbitaceae) on streptozotocin induced diabetic rats and its role in regulating carbohydrate metabolizing enzymes
}

\section{Meenatchi Packirisamy ${ }^{1,2}$, Purushothaman Ayyakkannu ${ }^{2}$ and Maneemegalai Sivaprakasam ${ }^{1}$,*}

\author{
${ }^{1}$ Department of Biochemistry. Bharathidasan University Constituent College for \\ Women. Orathanadu 614 625. Thanjavur-District. Tamil Nadu. India. Email: \\ maneedevi@yahoo.co.in. \\ ${ }^{2}$ Post-Graduate \& Research Department of Biochemistry. Mohamed Sathak College \\ of Arts and Science. Chennai 600 119. Tamil Nadu. India.
}

\begin{abstract}
Coccinia grandis (L.) Voigt (Cucurbitales: Cucurbitaceae) is a climbing perennial herb, growing throughout India and it is widely used in the traditional treatment of diabetes. The aim of present study was to evaluate the antidiabetic potential of the mature unripe of Coccinia grandis in streptozotocin (STZ)-induced diabetic rats with special reference to carbohydrate metabolizing enzymes. The optimum dose of Coccinia grandis extract (GCE) was determined by oral glucose tolerance test. The effects of CGE were compared with glibenclamide. Oral administration of Coccinia grandis extract at a concentration of $250 \mathrm{mg} / \mathrm{kg}$ body weight once daily to diabetic rats for the period of 30 days resulted in significant reduction in the levels of plasma glucose and glycosylated hemoglobin. Administration of CGE showed a significant increase in the levels of glycolytic enzymes and glycogen content and decrease in the levels of gluconeogenic enzymes in the liver of diabetic treated rats. The anti-hyperglycemic effect of the extract was comparable with glibenclamide, a known hypoglycemic drug. Present findings provide experimental evidence that the fruits of C. grandis have potential antidiabetic activity which might be used as a functional food and safe remedy for the treatment of diabetes and associated complications.
\end{abstract}

Keywords: Coccinia grandis; Streptozotocin; Antihyperglycemic effect; Glibenclamide; Carbohydrate metabolizing enzymes.
Received

September 4, 2018

Accepted

November 23, 2018

Released

December 31, 2018

Full Text Article

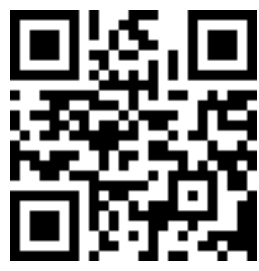

ORCID

(D) 0000-0003-2540-9008

Meenatchi

Packirisamy

D 0000-0001-5018-5515

Purushothaman

Ayyakkannu

(D) 0000-0002-8932-4540

Maneemegalai

Sivaprakasam 


\section{Introduction}

Diabetes mellitus is a metabolic disease affecting millions of individuals worldwide, characterized by absolute or relative deficiencies in insulin secretion and/or insulin action associated with chronic hyperglycemia and disturbances of carbohydrate, lipid and protein metabolism (Wild et al., 2004; Araki et al., 2017). WHO estimates that, globally, 422 million adults aged over 18 years were living with diabetes in 2014. Worldwide, the number of people with diabetes has substantially increased between 1980 and 2014, rising from 108 million to current number (422 million). Forty per cent of this increase is estimated to result from population growth and ageing, 28\% from a rise in age-specific prevalences and 32\% from the interaction of the two (WHO 2016). According to WHO report 2016, the total burden of deaths from high blood glucose in 2012 has been estimated to amount to 3.7 million. This number includes 1.5 million diabetes deaths, and an additional 2.2 million deaths from cardiovascular diseases, chronic kidney disease, and tuberculosis related to higher-than-optimal blood glucose. Therefore, novel concepts in the management of diabetes have aroused a curiosity among researchers throughout the world. In countries such as India and China, use of herbal medicines is a very common practice from ancient time, and herbal medicines are considered to be much safer and less expensive therapeutic strategies for the treatment of various diseases. A proper scientific investigation of the traditional herbal remedies can provide valuable leads for the development of alternative drugs and strategies for the management of diabetes (Ambady and Chamukuttan, 2008). Role of herbs in the management and control of diabetes has emerged fast over the years with the discovery of hypoglycemic effect of Mormodica charantia (Bitter Melon) (Welihinda et al., 1986; Ali et al., 1993).

Liver is an insulin dependent tissue which is severely affected during diabetes mellitus, Decreased activities of glycolytic and pentose phosphate pathway enzymes with concomitant increase in the activities of gluconeogenic and glycogenolytic enzymes have been reported (McAnuff et al., 2005) in diabetes mellitus. The glucose homeostasis is one of the pivotal therapeutic modality in the management diabetes. Acarbose, voglibose and miglitol are the inhibitors of carbohydrate metabolizing enzymes have been used clinically to control postprandial hyperglycemia in diabetics (Subramanian et al., 2008). Recently there has been a growing interest in hypoglycemic agents from natural products, especially those derived from plants. Plant sources are usually considered to be non-toxic, with fewer side effects than synthetic sources. Many medicinal plants have been found to be useful for the successful management of diabetes (Stamp, 2003).

Coccinia grandis (L.) Voigt belongs to the Cucurbitaceae Family and grows abundantly in India. It is a climbing perennial herb, growing throughout India especially in warmer and humid climatic conditions. It is widely used in traditional treatment of diabetes (Venkateswaran and Pari, 2002) The fruits are used for culinary purposes as a vegetable. Scientific investigations have supported the efficacy of leaf and root extracts in amelioration of diabetic complications (Venkateswaran and Pari, 2003; Akhtar et al., 2007). Coccinia indica leaves have been reported to stimulate insulin secretion in diabetic rats (Kumar et al., 1993).

Earlier studies from our laboratory provided experimental evidence that the fruits of Coccinia grandis have potential antidiabetic activity presumably by its antioxidant and antiglycation potential and its 
insulinotrophic properties in RINm5F cells in vitro (Meenatchi et al., 2017). Therefore, the present study was designed to investigate the effect of mature unripe Coccinia grandis on glucose utilization pathways and on hepatic glucose production since both of them contributes significantly to plasma glucose levels. For this, the activities of key enzymes of carbohydrate metabolism (glucose utilization/ production) are measured in streptozotocin-induced diabetic rats. The results were also compared with glibenclamide as a reference drug.

\section{Materials and methods}

\section{Source of chemicals}

Streptozotocin (STZ) and other fine chemicals were purchased from Sigma-Aldrich (St Louis, MO, USA). All other chemicals, reagents and solvents used were of good quality and analytical grade and obtained from SISCO Research Laboratories (SRL) and SD fine chemicals, Mumbai, India.

\section{Plant material}

Coccinia grandis (L.) Voigt mature unripe whole fruits were collected from Southern part of India (Kancheepuram District, Tamil Nadu, India) during the month of July 2017 and the pharmacognostic authentication was done by Dr. K. N. Sunil Kumar, RO and HOD, Pharmacognosy and Dr. M. Kannan, RO (Siddha) and In Charge, Siddha Central Research Institute, Arignar Anna Government Hospital Campus (Central Council for Research in Siddha, Department of AYUSH, Ministry of Health and Family Welfare, Government of India), Chennai-600 106 (Voucher Specimen 017112402B). The fruits were cut in to small slices, air dried under shade, pulverized to fine powder using a laboratory scale cutting mill.

\section{Extraction procedure}

The extract was prepared using the methods described by Stefanović et al. (2015) with minor modifications. The dried, ground plant material was extracted by maceration with methanol. Fifty g of plant material was soaked with $500 \mathrm{~mL}$ of the solvent for $24 \mathrm{~h}$ at room temperature in a shaker. The sample was filtered through filter paper. The residue from the filtration was extracted again, twice, using the same procedure. The filtrates obtained were combined and then evaporated to dryness using a rotary evaporator at $40{ }^{\circ} \mathrm{C}$. The obtained Coccinia grandis extract (GGE) was stored in sterile sample tube at $-20^{\circ} \mathrm{C}$.

\section{Phytochemical analysis of CGE \\ Preliminary phytochemical} analyses of the CGE were done using standard procedures of Sofowora (1993) and Harbourne (1998).

\section{Determination of total phenolic content}

The amount of total phenolics in CGE was determined by the method of Singleton et al. (1999) with minor modifications. One hundred $\mathrm{mL}$ of crude extract $(20 \mathrm{mg} / \mathrm{mL})$ was mixed with 0.2 $\mathrm{mL}$ of Folin-Ciocalteu reagent, $2 \mathrm{~mL}$ of distilled water and $1 \mathrm{~mL}$ of $15 \% \mathrm{Na} 2 \mathrm{CO} 3$. The mixture was measured at $765 \mathrm{~nm}$ using UV-Visible spectrophotometer (T60U, PG Instruments Limited, UK) after $2 \mathrm{~h}$ at room temperature. Gallic acid was used as a standard and the total phenolics were expressed as mg of gallic acid equivalent (mg GAE) per g of extract (dry weight).

\section{Determination of total flavonoid content}

Total flavonoid content was determined using the method of Chang et al. (2002) with some modifications using quercetin as the standard. A calibration curve of quercetin was prepared in the range of $0-200 \mathrm{mg} / \mathrm{mL}$. Briefly, extract $(0.5 \mathrm{~mL})$ and standard $(0.5 \mathrm{~mL})$ were placed in different test tubes and to each $10 \%$ aluminum chloride $(0.1 \mathrm{~mL}), 1 \mathrm{M}$ potassium acetate $(0.1 \mathrm{~mL}), 80 \%$ methanol $(1.5 \mathrm{~mL})$ and distilled water 
(2.8 mL) were added and mixed. A blank was prepared in the same manner where $0.5 \mathrm{~mL}$ of distilled water was used instead of the sample or standard, and the amount of aluminum chloride was also replaced by distilled water. All tubes were incubated at room temperature for $30 \mathrm{~min}$. The absorbance was taken at 415 nm using UV-Visible spectrophotometer. The flavonoid content was expressed as mg quercetin equivalent (QE) per $g$ of extract.

\section{Determination of saponins and dietary fiber content}

Saponins in CGE extract was determined by standard method as described by Anhawange et al. (2004) The saponins were calculated as mg per $g$ of extract (dry weight). The dietary fiber content was analyzed by the enzymatic-gravimetric method of Asp et al. (1983) and expressed as g per $100 \mathrm{~g}$ of plant material.

\section{Animals studies}

Male albino Wistar rats weighing 200-220 g were used in this study. The rats were housed in clean polypropylene cages, maintained in the air-conditioned animal house with a constant photoperiod of $12 \mathrm{~h} \mathrm{light/dark} \mathrm{cycle} \mathrm{with}$ the light cycle from $6: 00 \mathrm{~h}$ to $18: 00 \mathrm{~h}$ and the dark cycle from $18: 00 \mathrm{~h}$ to $6: 00 \mathrm{~h}$. They were maintained at an ambient temperature of $25 \pm 2{ }^{\circ} \mathrm{C}$ and $12 / 12 \mathrm{~h}$ of light/dark cycle. Animals were given standard commercial rat chow and water ad libitum. The experiments were conducted according to the ethical norms approved by the Ministry of Social Justices and Empowerment, Government of India and Institutional Animal Ethics Committee (IAEC) Guidelines. Animal welfare and the experimental procedures were carried out strictly in accordance with the Guide for Care and Use of Laboratory Animals.

\section{diabetes}

Diabetes was induced in overnight fasted experimental rats by a single intraperitoneal injection of streptozotocin ( $40 \mathrm{mg} / \mathrm{kg}$ body weight) dissolved in freshly prepared citrate buffer (0.1 M, pH 4.5). Streptozotocin injected animals were allowed to drink $20 \%$ glucose solution overnight to overcome the initial drug-induced hypoglycemic mortality. Control rats were injected with same volume of citrate buffer alone. The animals were considered as diabetic, if their blood glucose values were above $250 \mathrm{mg} / \mathrm{dL}$ on the third day after STZ injection. The treatment was started on the third day after STZ injection and continued for 30 days at $24 \mathrm{~h}$ intervals during the entire period of the experiment.

\section{Oral glucose tolerance test}

Oral glucose tolerance test was performed according to the method of (Joy and Kuttan, 1999). After overnight fasting, 0 min blood sample $(0.2 \mathrm{~mL})$ was taken from control and experimental rats. Without delay, a glucose solution ( $2 \mathrm{~g} / \mathrm{kg}$ body weight) was administered orally. Blood was withdrawn from the retro orbital sinus at $30,60,90,120$ and 150 min interval. All the blood samples were collected with potassium oxalate and sodium fluoride solution for the estimation of glucose.

\section{Experimental design}

The animals were divided into seven groups of six animals in each. Different doses of CGE were administered orally using an intragastric tube for the period of 30 days. Antidiabetic drug glibenclamide was dissolved in distilled water and used as a standard drug.

$$
\begin{array}{ll}
\text { Group I } & \text { : Normal control } \\
\text { Group II } & \text { : Diabetic control } \\
\text { Group III } & : \text { Diabetic + CGE } \\
\text { mg/kg body weight) } \\
\text { Group IV } \quad \text { Diabetic + CGE }
\end{array}
$$$$
\text { (125 mg/kg body weight) }
$$$$
\text { (250 mg/kg body weight) }
$$ 


\author{
Group V : Diabetic + CGE \\ (500 mg/kg body weight) \\ Group VI : Diabetic + CGE \\ (750 mg/kg body weight) \\ Group VII : Glibenclamide \\ ( $5 \mathrm{mg} / \mathrm{kg}$ body weight)
}

After 30 days of treatment, the animals were deprived of food overnight and sacrificed by cervical decapitation. Blood was collected in a dry test tube and allowed to coagulate at ambient temperature for $30 \mathrm{~min}$. Serum was separated by centrifugation at $2000 \times \mathrm{g}$ for $10 \mathrm{~min}$ and used for the biochemical estimations. Blood was collected in tubes with a mixture of potassium oxalate and sodium fluoride (1:3) for the estimation of plasma insulin, glucose, and ethylenediamine tetra acetic acid (EDTA) for the estimation of hemoglobin, glycated hemoglobin. Liver was immediately dissected out and washed in ice-cold saline to remove the blood. Tissues was minced and homogenized $(10 \% \mathrm{w} / \mathrm{v})$ with $0.1 \mathrm{M}$ Tris-HCl buffer (pH 7.4) in ice cold condition. The homogenates were centrifuged at $1000 \times \mathrm{g}$ for $10 \mathrm{~min}$ then the supernatants were separated and used for enzyme assays.

\section{Biochemical analysis}

Plasma glucose was estimated by the Method of Trinder using a reagent kit Trinder (1969). Hemoglobin (Hb) and glycated hemoglobin (HbA1c) were estimated by the method of Drabkin and Austin (1932) and Sudhakar and Pattabiraman (1981), respectively. The plasma insulin was measured by the method of Bürgi et al., (1988). Glucokinase, glucose 6-phosphatase, fructose 1,6-bisphosphatase and glucose6-phosphate dehydrogenase were assayed in the tissues by the methods of Brandstrup et al., (1957), Koide and Oda (1956), Gancedo and Gancedo (1971) and Bergmeyer (1984), respectively. Glycogen content was determined as described by Morales et al., (1975). The estimation of protein was carried out by the method of Lowry et al., (1951).

\section{Histopathological analysis}

Formalin-fixed liver tissues from all groups were paraffin embedded, sectioned (3 $\mathrm{mm}$ thickness) and placed on glass slides. Paraffin-embedded sections of tissue were deparaffinised, rehydrated with graded alcohol and stained with Harris' haematoxylin and eosin (Dako, Glostrup, Denmark) in a Leica Autostainer (Wetzlar, Germany) and examined under a microscope.

\section{Statistical analysis}

Data were analyzed with SPSS Version 16 software. Hypothesis testing methods included one-way analysis of variance (ANOVA) followed by LSD. The values are expressed as mean \pm S.D. and the results were considered significantly different if $P$-values less than 0.05 . Statistically significant variations are compared as follows: Normal control rats versus drug control rats (CGE alone treated rats), control versus diabetic control, diabetic rats versus CGE treated diabetic rats and CGE treated diabetic rats versus glibenclamide treated diabetic rats.

\section{Results}

\section{Phytochemical studies}

The ethanol extract of Coccinia grandis (L.) Voigt were subjected for phytochemical screening, which reveals the presence of different compounds in plant extract such as alkaloid, glycoside, flavonoid, saponin, carbohydrate, fixed oil and fat, and tannins (Table 1). The percent yields of ethanol extract was found to be $6.87 \% \pm 0.47 \%$. 
Table 1. Preliminary phytochemical screening of ethanol extract of mature unripe Coccinia grandis (L.) Voigt.

\begin{tabular}{llc}
\hline Test & \multicolumn{1}{c}{ Observation } & Inference \\
\hline Alkaloids & Brown precipitate formed. & + \\
Flavonoids & Reddish pink color was observed. & + \\
Saponins & Layer of foam did not form. & + \\
& White precipitate did not form. & + \\
Carbohydrates & A brown ring was observed. & + \\
Phenols & Blue green color was observed. & + \\
Terpenoids & Reddish violet color was observed. & \\
& A purple color was not observed. & + \\
Phytosterols & Bluish green color was observed. & + \\
& Red color was observed. & + \\
\hline
\end{tabular}

+ indicates presence; - indicates absence.

\section{Total phenolics, flavonoids, saponins and dietary fiber}

It is well known that phenolic compounds belong to the bioactive components of plant products and have good health-promoting activities. Saponins are the glycosidic compounds found in most of the plants and have been reported to possess anticarcinogenic and antifungal activity.
In this study, the total phenolic and flavoniod contents were quantified and found to be $14.72 \pm 1.65 \mathrm{mg}$ GAE per $\mathrm{g}$, $7.35 \pm 0.67 \mathrm{mg}$ QE per g of extract (dry weight), respectively. The saponins and dietary fiber contents were found to be $0.092 \pm 0.02 \mathrm{mg}$ per $\mathrm{g}$ of extract and $41.97 \mathrm{~g}$ per $100 \mathrm{~g}$ of plant material, respectively. (shown in Table 2).

Table 2. Total phenolic, flavonoid, saponin and fiber contents in ethanol extract of Coccinia grandis (L.) Voigt.

\begin{tabular}{lc}
\multicolumn{1}{c}{ Parameter } & Concentration \\
\hline Total Phenolic Contents $^{\mathrm{a}}$ & $14.72 \pm 1.65$ \\
Total Flavonoid Contents $^{\mathrm{b}}$ & $7.35 \pm 0.67$ \\
Total Saponins $^{\mathrm{c}}$ & $0.092 \pm 0.02$ \\
Soluble Dietary Fiber $^{*}$ & $9.65 \pm 0.08$ \\
Insoluble Dietary Fiber $^{*}$ & $32.32 \pm 1.89$ \\
\hline
\end{tabular}

Each value is expressed as mean \pm SD from minimum of three independent experiments. ${ }^{a}$ Data expressed as milligram of gallic acid equivalent (mg GAE) per g of extract (dry weight). ${ }^{\mathrm{b}}$ Data expressed as milligram of quercetin equivalent (mg QE) per g of extract (dry weight). ${ }^{c}$ Data expressed as milligram per g of extract (fresh weight). * Data expressed as gram per $100 \mathrm{~g}$ of plant material. 


\section{diabetic rat \\ Oral glucose tolerance test in}

Results of oral glucose tolerance test conducted on normal and experimental rats are shown in Figure 1. The blood glucose level in both normal and drug alone treated control rats showed a high peak value at 30 and 60 min after glucose load and decreased to near normal at $120 \mathrm{~min}$. In diabetic rat the blood glucose levels reached the peak value at $30 \mathrm{~min}, 60 \mathrm{~min}$ and remain higher even after $120 \mathrm{~min}$. But in the case of diabetic rats treated at a dose of $250 \mathrm{mg} / \mathrm{kg}$ body weight showed significant decrease in blood glucose level $(183.15 \pm 11.4$ at $90 \mathrm{~min}$; 174.53 .5 \pm 9.9 at $120 \mathrm{~min}$ and $158.58 \pm 8.2$ at 150 min) which were similar to that of glibenclamide treated diabetic rats. The maximum glucose lowering effect of the extract was observed at a dose of 250 $\mathrm{mg} / \mathrm{kg}$ body weight than the other two doses. Therefore, further studies were carried out with this dose.

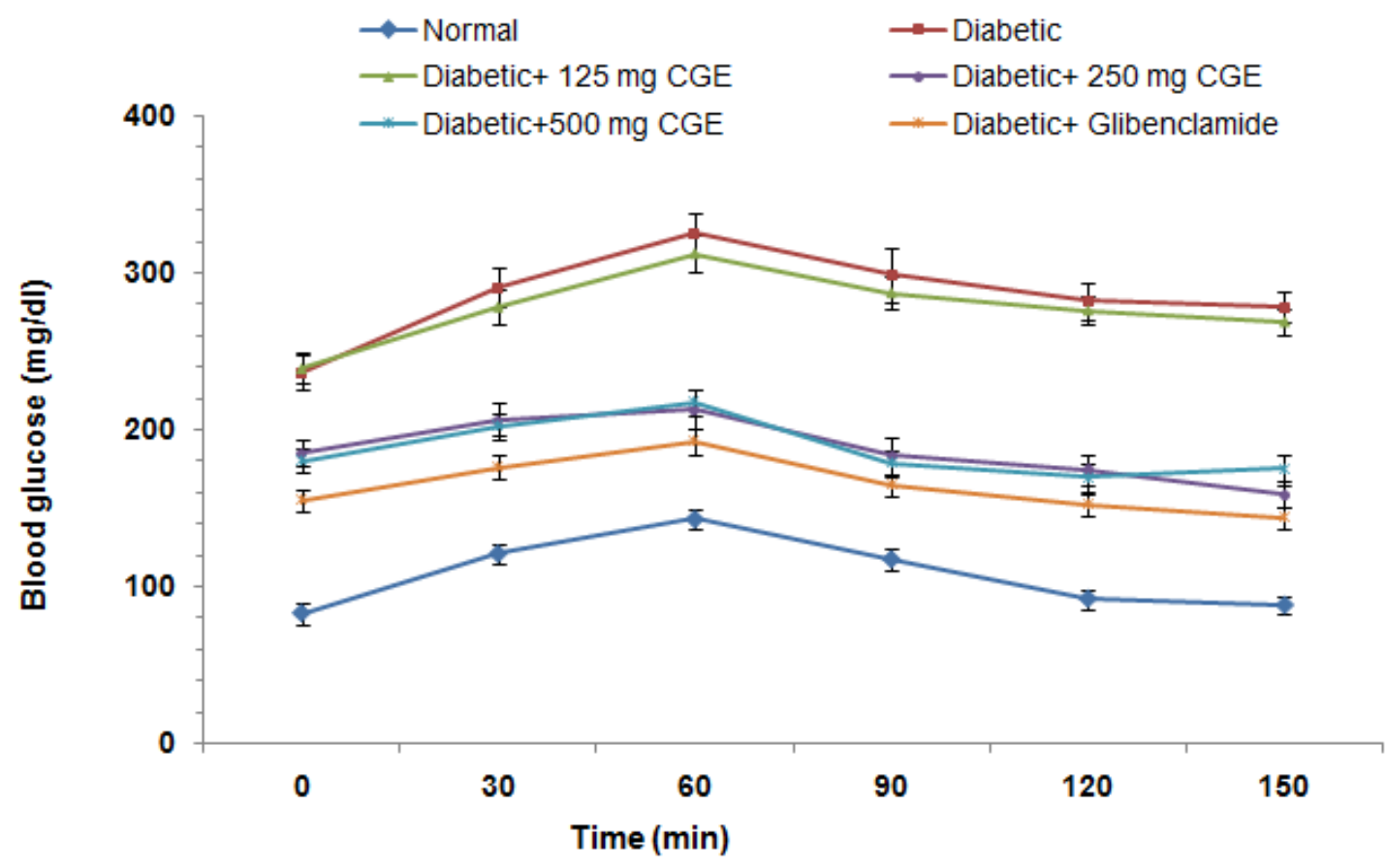

Figure 1. Oral glucose tolerance test (GTT).

\section{Effect of CGE on Body weight changes and levels of glucose, insulin, hemoglobin and glycosylated hemoglobin}

The changes in the body weight and the levels of plasma glucose, insulin, $\mathrm{Hb}$, and HbA1c in normal and diabetic rats were depicted in Table 3 and Table 4, respectively. Food intake was significantly increased whereas the body weight significantly decreased in diabetic rats compared with normal control. Administration of CGE or glibenclamide to diabetic rats resulted in significant increase in body weight. The levels of plasma glucose and HbA1c were significantly increased whereas the levels of insulin and $\mathrm{Hb}$ were significantly decreased in the diabetic rats compared control rats. On treatment 
with CGE or glibenclamide reversed these values to near normal in diabetic rats. Administrations of CGE to normoglycemic rats showed no significant changes in the above said parameters.

Table 3. Effect of CGE on body weight in control and experimental animals during 30 days treatment.

\begin{tabular}{|l|c|c|c|}
\hline \multirow{2}{*}{ Animal Groups } & \multicolumn{2}{|c|}{ Body weight (g) } & \multirow{2}{*}{ Change (\%) } \\
\cline { 2 - 3 } & Initial & Final & \\
\hline Normal control & $202.6 \pm 4.28$ & $229.8 \pm 3.55^{\mathrm{a}}$ & 13.43 \\
\hline Normal + 250 mg CGE & $206.5 \pm 3.76$ & $235.2 \pm 3.58$ & 12.93 \\
\hline Diabetic control & $205.7 \pm 5.14$ & $190.3 \pm 4.62^{\mathrm{b}}$ & $-7.49^{\mathrm{b}}$ \\
\hline Diabetic $+250 \mathrm{mg}$ CGE & $211.3 \pm 4.17$ & $225.8 \pm 3.56^{\mathrm{c}, \mathrm{d}}$ & $6.86^{\mathrm{c}, \mathrm{d}}$ \\
\hline Diabetic $+5 \mathrm{mg}$ GBE & $208.5 \pm 4.87$ & $224.4 \pm 2.78^{\mathrm{f}}$ & $7.63^{\mathrm{f}}$ \\
\hline
\end{tabular}

Values are given as mean \pm S.D. for six animals in each group. Values are considered significantly different at $P<0.05$ with post hoc LSD test. a Control vs CGE treated normal control rats. ${ }^{b}$ Control rats vs Diabetic rats. ${ }^{c}$ Control vs CGE treated diabetic rats. ${ }^{d}$ Diabetic rats vs CGE treated diabetic rats. ${ }^{\mathrm{e}} \mathrm{CGE}$ treated diabetic rats vs Glibenclamide. ${ }^{\mathrm{f}}$ Glibenclamide vs Diabetic rats.

Table 4. Effect of CGE on the levels of glucose, insulin, hemoglobin and glycosylated hemoglobin in control and experimental animals during 30 days treatment.

\begin{tabular}{|l|c|c|c|c|}
\hline Animal Groups & $\begin{array}{c}\text { Glucose } \\
(\mathbf{m g} / \mathbf{d L})\end{array}$ & $\begin{array}{c}\text { Insulin } \\
(\boldsymbol{\mu U} / \mathbf{m L})\end{array}$ & $\begin{array}{c}\text { Hb } \\
(\mathbf{g} / \mathbf{d L})\end{array}$ & $\begin{array}{c}\text { HbA1c } \\
(\mathbf{m g} / \mathbf{g} \text { of } \mathbf{~ H b})\end{array}$ \\
\hline Normal control & $107.65 \pm 2.86^{\mathrm{a}}$ & $14.28 \pm 0.62$ & $14.58 \pm 1.36$ & $0.53 \pm 0.042$ \\
\hline Normal $+250 \mathrm{mg}$ CGE & $101.24 \pm 3.25$ & $13.86 \pm 0.46$ & $13.69 \pm 1.48$ & $0.55 \pm 0.036$ \\
\hline Diabetic control & $289.65 \pm 22.63^{\mathrm{b}}$ & $5.85 \pm 0.43^{\mathrm{b}}$ & $9.45 \pm 0.87^{\mathrm{b}}$ & $1.26 \pm 0.027^{\mathrm{b}}$ \\
\hline Diabetic + 250 mg CGE & $154.36 \pm 4.64^{\mathrm{c}, \mathrm{d}}$ & $8.87 \pm 0.52^{\mathrm{c}, \mathrm{d}}$ & $10.80 \pm 1.06^{\mathrm{c}, \mathrm{d}}$ & $0.62 \pm 0.039^{\mathrm{c}, \mathrm{d}}$ \\
\hline Diabetic + 5 mg GBE & $138.45 \pm 4.59^{\mathrm{e}, \mathrm{f}}$ & $11.57 \pm 0.72^{\mathrm{f}}$ & $11.67 \pm 1.21^{\mathrm{f}}$ & $0.59 \pm 0.023^{\mathrm{f}}$ \\
\hline
\end{tabular}

Values are given as mean \pm S.D. for six animals in each group. Values are considered significantly different at $P<0.05$ with post hoc LSD test. a Control vs CGE treated normal control rats. ${ }^{b}$ Control rats vs Diabetic rats. ${ }^{c}$ Control vs CGE treated diabetic rats. ${ }^{d}$ Diabetic rats vs CGE treated diabetic rats. ${ }^{\mathrm{e}} \mathrm{CGE}$ treated diabetic rats vs Glibenclamide. ${ }^{\mathrm{f}}$ Glibenclamide vs Diabetic rats.

\section{enzymes \\ Effect of CGE on hepatic key}

Table 5 shows the activities of carbohydrate metabolizing enzymes and the hepatic glycogen content in the liver of control and experimental rats. The activities of hexokinase, glucose-6- phosphate dehydrogenase and glycogen content were significantly decreased in the liver of diabetic rats when compared to control rats. Oral administration of CGE or glibenclamide reversed these parameters to near normalcy. 
Table 5. Effect of CGE on hexokinase, glucose-6-phosphate dehydrogenase and glycogen content in the liver of control and experimental animals during 30 days treatment.

\begin{tabular}{|l|c|c|c|}
\hline Animal groups & Hexokinase & $\begin{array}{c}\text { Glucose-6-phosphate } \\
\text { dehydrogenase }\end{array}$ & Glycogen content \\
\hline Normal control & $108.79 \pm 5.65^{\mathrm{a}}$ & $2.65 \pm 0.18$ & $53.64 \pm 4.13$ \\
\hline $\begin{array}{l}\text { Normal + } 250 \mathrm{mg} \\
\text { CGE }\end{array}$ & $112.62 \pm 4.92$ & $2.72 \pm 0.22$ & $56.47 \pm 3.96$ \\
\hline Diabetic control & $87.53 \pm 3.57^{\mathrm{b}}$ & $1.38 \pm 0.14^{\mathrm{b}}$ & $13.60 \pm 2.78^{\mathrm{b}}$ \\
\hline $\begin{array}{l}\text { Diabetic }+250 \mathrm{mg} \\
\text { CGE }\end{array}$ & $98.64 \pm 4.63^{\mathrm{c}, \mathrm{d}}$ & $1.72 \pm 0.13^{\mathrm{c}, \mathrm{d}}$ & $38.14 \pm 2.85^{\mathrm{c}, \mathrm{d}}$ \\
\hline Diabetic $+5 \mathrm{mg}$ GBE & $107.56 \pm 3.87^{\mathrm{e}, \mathrm{f}}$ & $2.23 \pm 0.26^{\mathrm{f}}$ & $43.42 \pm 4.21^{\mathrm{f}}$ \\
\hline
\end{tabular}

Values are given as mean \pm S.D. for six animals in each group. Values are considered significantly different at $P<0.05$ with post hoc LSD test. a Control vs CGE treated normal control rats. ${ }^{\text {b }}$ Control rats vs Diabetic rats. ${ }^{c}$ Control vs CGE treated diabetic rats. ${ }^{d}$ Diabetic rats vs CGE treated diabetic rats. ${ }^{\mathrm{e}} \mathrm{CGE}$ treated diabetic rats vs Glibenclamide. ${ }^{\mathrm{f}}$ Glibenclamide vs Diabetic rats.

Table 6 depicts the activities of gluconeogenic enzymes in the liver of control and experimental rats. Glucose-6phosphatase and fructose 1,6biphosphatase activities were significantly increased in diabetic rats. Oral administrations of CGE or glibenclamide to diabetic rats reversed the activities of these hepatic enzymes to near normal.

Table 6. Effect of CGE on activities of Glucose-6-phosphatise and fructose-1,6- bisphosphatase in the liver of control and experimental animals during 30 days treatment.

\begin{tabular}{|l|c|c|}
\hline Animal Groups & Glucose-6-phosphatase & Fructose-1,6-bisphosphatase \\
\hline Normal control & $0.12 \pm 0.02^{\mathrm{a}}$ & $4.88 \pm 0.33$ \\
\hline Normal + 250 mg CGE & $0.12 \pm 0.01$ & $5.27 \pm 0.52$ \\
\hline Diabetic control & $0.31 \pm 0.03^{\mathrm{b}}$ & $8.26 \pm 0.41^{\mathrm{b}}$ \\
\hline Diabetic + 250 mg CGE & $0.08 \pm 0.04^{\mathrm{c}, \mathrm{d}}$ & $3.72 \pm 0.36^{\mathrm{c}, \mathrm{d}}$ \\
\hline Diabetic $+5 \mathrm{mg} \mathrm{GBE}$ & $0.11 \pm 0.03^{\mathrm{e}, \mathrm{f}}$ & $4.12 \pm 0.24^{\mathrm{f}}$ \\
\hline
\end{tabular}

Values are given as mean \pm S.D. for six animals in each group. Values are considered significantly different at $P<0.05$ with post hoc LSD test. a Control vs CGE treated normal control rats. ${ }^{b}$ Control rats vs Diabetic rats. ${ }^{c}$ Control vs CGE treated diabetic rats. ${ }^{d}$ Diabetic rats vs CGE treated diabetic rats. ${ }^{\mathrm{e}}$ CGE treated diabetic rats vs Glibenclamide. ${ }^{\mathrm{f}}$ Glibenclamide vs Diabetic rats.

\section{Histopathological analysis}

Figure 2 shows the histopathological examination of liver sections of control and experimental group of animals, stained with haematoxylin and eosin, viewed at $10 \mathrm{X}$. Normal control group and normal +250 mg CGE treated rats showed normal cellular architecture of liver. Diabetic induced group show hepatocytes with loss of architecture, necrosis, fatty changes and are looking pale. Diabetic rats treated with $250 \mathrm{mg}$ and $5 \mathrm{mg}$ glibenclamide treated rats showed normal cellular architecture with distinct hepatic cells and sinusoidal spaces. 

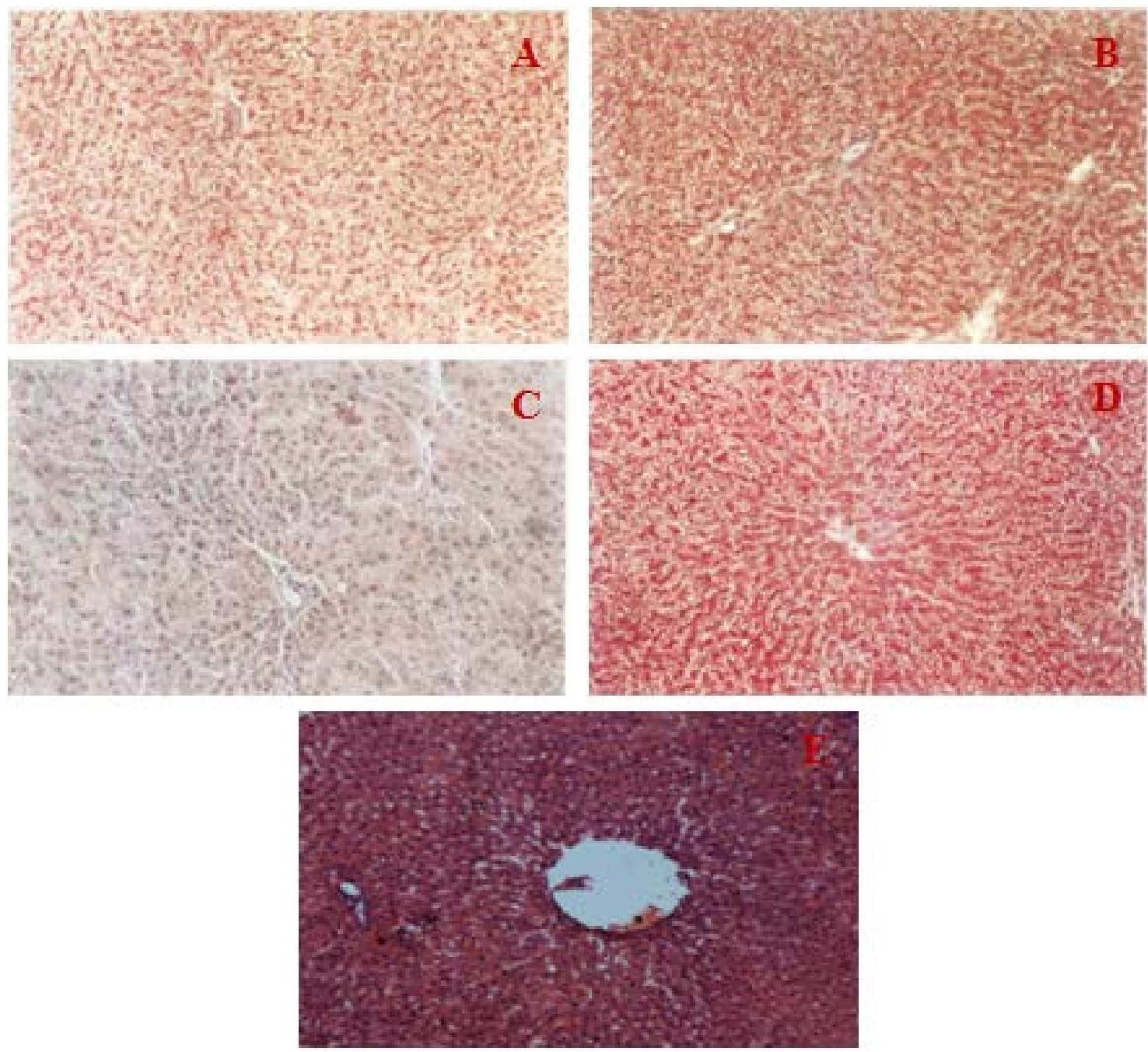

Figure 2. Histopathological examination of liver sections of control and experimental group of animals. Stained with haematoxylin and eosin (10X). A. Normal control group rats shows normal cellular architecture of liver; B. Normal + 250 mg CGE treated shows normal cellular architecture of liver; C. Diabetic induced group showing hepatocytes with loss of architecture, necrosis, fatty changes and are looking pale. D. Diabetic + $250 \mathrm{mg}$ CGE treated; and E. Diabetic + glibenclamide treated rats show normal cellular architecture with distinct hepatic cells and sinusoidal spaces.

\section{Discussion}

Phytochemical screening is of paramount importance in identifying new source of therapeutically valuable compounds having medicinal significance, to make the best and judicious use of available natural wealth (Mungole et al., 2010). This study has focused on both the phytochemical screening and antidiabetic effect of $C$. grandis. Screening of the CGE revealed the presence of phytochemicals such as phenols, tannins, flavonoids, saponins, steroids, and alkaloids. The phenolic compounds are one of the largest and most ubiquitous groups of plant metabolites and attracted a great attention in relation to their potential for beneficial effects on health (Mourya et al., 2017). Thus, the anti hyperglycemic activity of the CGE as recorded in this study might be attributed to the presence of high phenolic and flavonoid contents. 
The saponins content was found to be $0.092 \pm 0.02 \mathrm{mg}$ per $\mathrm{g}$ of extract. The dietary fiber content of CGE was analyzed by the enzymatic-gravimetric method and the extract showed good amounts of both soluble and insoluble fibers $(41.97 \pm 1.62 \mathrm{~g}$ per $100 \mathrm{~g}$ of plant material). Pectin is a soluble fiber that affects blood glucose levels either by decreasing the transit time or indirectly through the production of short chain fatty acids (SCFAs). Propionate, butyrate and acetate are the commonly produced SCFAs obtained by anaerobic fermentation of dietary fiber components by the microflora in the large intestine. Thus, the high dietary fiber content of CGE recorded in the present study correlate the beneficial effects of CGE in the diabetic condition (Smith et al., 1998; Gao et al., 2009).

In our study, initial and final body weight of control and experimental rats were measured whereas the food and fluid intake were evaluated on daily basis. Rise in insulin levels upon treatment with CGE or glibenclamide in diabetic animals resulted in improved glycemic control which prevented the loss of body weight and excess of food and fluid intake. Streptozotocin-induced diabetic animals displayed the following characteristics polyuria, increased water intake, dehydration, weight loss and muscle wasting, excessive hair loss and scaling, diarrhea, cataracts and increased food intake (Wei et al., 2003). Decrease in body weight of diabetic rats is due to catabolism of fats and proteins. Due to insulin deficiency, the protein content is decreased in muscular tissue by proteolysis (Babu et al., 2007).

The streptozotocin-induced

diabetic rats showed significant reduction in plasma glucose and significant increase in insulin levels on treatment CGE. The antihyperglycemic action of the extract was observed in a dose dependent manner. As far as the most effective dose is concerned, 250 $\mathrm{mg} / \mathrm{kg}$ body weight of CGE was found to be more effective than the other two doses. This dose was as effective as that of synthetic drug glibenclamide especially during oral glucose tolerance test (OGTT) and is an essential trigger for the liver to revert its normal homeostasis during experimental diabetes. CGE might bring about glucose lowering action through stimulation of either surviving $\beta$ cells or regenerated $\beta$ cells of islets of Langerhans to release more insulin from the pancreas. This was clearly evidenced by increased levels of plasma insulin in diabetic rats treated with CGE. Earlier findings from our laboratory have also reported the insulinotrophic (insulin secretory) properties of Coccinia grandis extract in RINm5F cells in vitro (Meenatchi et al., 2017). In addition to insulinotrophic property, other possible mechanism of action of CGE could be correlated with reminiscent effect of hypoglycemic sulphonylurea that promotes insulin secretion by the closure of $\mathrm{K}^{+}$-ATP channels, membrane depolarization and stimulation of $\mathrm{Ca}^{2+}$ influx, an initial key step in insulin secretion from the remnant $\beta$ cells or from regenerated $\beta$ cells of pancreas (Fuhlendorff et al., 1998). Saponins and alkaloids (present in the extract) had this protective effect by scavenging ROS species, which destroys the $\beta$ cells in the pancreas. The restorative effect on $\beta$ cells of due to the action of flavonoids present could speculate to normal blood glucose level, and this was also observed in the study of Tiware and Roa, (2002) using flavonoid extract of Pterocarpus marsupium. The flavonoids have also been reported to inhibit aldose reductase activity, which is beneficial in mitigating the glucose autoxidation, glycation and acts against the major contributor ROS and other free radical (Tiware and Roa, 2002). This would lead to regeneration $\beta$ cells and led to the normal levels of blood glucose in STZ- induced diabetic rats treated with CGE.

Advanced glycation end-products (AGEs) are the final products derived from the Maillard reaction, which is a non-enzymatic glycation of free amino 
groups by sugars and aldehydes. AGE formation begins under hyperglycemic or oxidative stress conditions as observed in STZ-induced diabetic rats and is characterized by conversion of reversible Schiff-base adducts to covalently bound Amadori products, which undergo further rearrangements that terminate in the formation of irreversibly bound compounds known as AGEs (Thornalley, 2005; Nenna et al., 2015) The interaction of AGEs with receptors for AGEs (RAGE) directly activates multiple intracellular signaling, gene expression, and the secretory proinflammatory molecules accompanied by increasing free radicals that contribute towards pathologic complications related to diabetes (Caengprasath et al., 2013). The glycosylated hemoglobin (HbA1c) levels are monitored as a reliable index of glycemic control in diabetes and it was found to increase in patients with diabetes mellitus due to glycosylation of hemoglobin and the amount of increase was directly proportional to the fasting blood glucose levels (Babu et al., 2007). During diabetes, the excess glucose present in blood reacts with hemoglobin. Therefore, the total hemoglobin level is decreased in diabetic rats (Ananda et al., 2012). Administration of GGE and glibenclamide prevented a significant elevation in glycosylated hemoglobin thereby increasing the level of total hemoglobin in diabetic rats. This could be due to the result of improved glycemic control produced by CGE.

Liver is a general metabolic organ that plays a pivotal role in glycolysis and gluconeogenesis. A partial or total deficiency of insulin causes derangement in carbohydrate metabolism that decreases activity of several key enzymes including glucokinase, hexokinase, phosphofructokinase and pyruvate kinase, resulting in impaired peripheral glucose utilization and increased hepatic glucose production. In our study, the activities of hexokinase and glucose-6phosphate dehydrogenase have been decreased in diabetic rats, which may either be due to insulin deficiency or loss of insulin receptors (Saravanan and Pugalendi, 2005). One of the key enzymes in the metabolism of glucose is hexokinase, which phosphorylates glucose into glucose-6-phosphate (Pari and Rajarajeswari, 2009). The activity of this enzyme was decreased in the liver of STZ- diabetic rats. Administration of CGE to STZ- induced rats resulted in an increased activity of liver hexokinase. The increased activity of hexokinase can cause increased glycolysis and increased utilization of glucose for energy production (Jayanthi et al., 2010). CGE has been observed to reduce the levels of glucose in the blood. The decrease in the concentration of blood glucose in STZinduced rats treated with CGE may be due to increased glycolysis (increased liver hexokinase activity). The activity of glucose-6-phosphate dehydrogenase was decreased which slows down the pentose phosphate pathway in diabetic conditions. In our study, administration of CGE significantly increased the activity of glucose-6- phosphate dehydrogenase in diabetic state. It provides hydrogen, which binds NADP+ and produces NADPH and enhances the synthesis of fats from carbohydrates, i.e., lipogenesis (Bopanna et al., 1997) finally the plasma glucose levels were decreased.

$\begin{array}{ccc}\text { Liver plays a vital role in } \\ \text { buffering } & \text { the } & \text { postprandial }\end{array}$ hyperglycemia and is involved in synthesis of glycogen. Diabetes mellitus is known to impair the normal capacity of the liver to synthesize glycogen (Sirag, 2009). Synthase phosphatase activates glycogen synthase, resulting in glycogenesis. This activation step appears to be defective in STZ- induced diabetic rats (Kirana and Srinivasan, 2008). Diabetic rats treated with CGE had liver glycogen brought back to near normal levels, which could be due to increased secretion of insulin, which enhances glycogenesis.

The hepatic gluconeogenic enzymes (glucose-6-phosphatase and fructose-1, 6-bisphosphatase) were 
significantly increased in diabetic state (Shulman, 2000). The activities of the two enzymes may be due to the increased synthesis of enzymes contributing to the increased glucose production during diabetes by the liver (Pari and Saravanan, 2005).The gluconeogenic enzyme glucose-6phosphatase is a crucial enzyme of glucose homeostasis because it catalyses the ultimate biochemical reaction of both glycogenolysis and gluconeogenesis (Singh and Kakkar, 2009). Increased hepatic glucose production in diabetes mellitus is associated with impaired suppression of the gluconeogenic enzyme fructose-1,6-bisphosphatase. Activation of gluconeogenic enzymes is due to the state of insulin deficiency, because under normal conditions, insulin functions as a suppressor of gluconeogenic enzymes.

\section{Conclusion}

Based on this study, it can be concluded that the culinary plant Coccinia grandis (L.) Voigt represent as a good candidate for alternative and/or complementary medicine in the management of diabetes mellitus. Since, it exhibited anti-hyperglycemic potential through improving insulin secretion and modulating the carbohydrate metabolizing enzymes. However, as this is only preliminary study, further studies are in progress to identify the active constituents and their molecular mechanisms in vivo.

\section{Conflicts of interest}

Authors declare that they have no conflict of interests.

\section{References}

Akhtar, M. A.; Rashid, M.; Wahed, M. I. I; Islam, M. R.; Shaheen, S. M.; Islam, M. A.; Amran, M. S.; Ahmed, M. Comparison of long term antihyperglycemic and hypolipidemic effects between Coccinia cordifolia (Linn.) and Catharanthus roseus (Linn.) in alloxaninduced diabetic rats. Research Journal of Medicine and Medical Sciences, v. 2, no. 1, p. 29-34, 2007.

Ali, L.; $\quad$ Khan, $\quad$ A. K.; $\quad$ Mamun, M. I.; Mosihuzzaman, M.; Nahar, N.; Nur-e-Alam, M.; Rokeya, B. Studies on hypoglycemic effects of fruit pulp, seed, and whole plant of Momordica charantia on normal and diabetic model rats. Planta Medica, v. 59, no. 5, p. 408-412, 1993. https://doi.org/10.1055/s2006-959720

Ambady, R.; Chamukuttan, S. Early diagnosis and prevention of diabetes in developing countries. Reviews in Endocrine and Metabolic Disorders, v. 9, no. 3, p. 193-201, 2008. https://doi.org/10.1007/s11154-0089079-z

Ananda, P. K.; Kumarappan, C. T.; Sunil, C.; Kalaichelvan, V. K. Effect of Biophytum sensitivum on streptozotocin and nicotinamide-induced diabetic rats. Asian Asian Pacific Journal of Tropical Biomedicine, v. 2, no. 1, p. 31-35. 2012. https://doi.org/10.1016/S2221-1691(11) 60185-8

Anhawange, A. A.; Ajibola, V. O.; Oniye, S. J. Chemical studies of seeds of Moronga oleifera (Lam) and Detarium microcarpum (Guill and Sperr). Journal of Biological Sciences, v. 4, p. 711-715, 2004. https://doi.org/10.3923/ jbs.2004.711.715

Araki, E.; Haneda, M.; Kasuga, M.; Nishikawa, T.; Kondo, T.; Ueki, K.; Kadowaki, T. New glycemic targets for patients with diabetes from the Japan Diabetes Society. Journal of Diabetes Investigation, v. 8, no. 1, p. 123125, 2017. https://doi.org/10.1111/jdi. 12600

Asp, N. G.; Johansson, C. G.; Hallmer, H.; Siljestroem, M. Rapid enzymic assay of insoluble and soluble dietary fiber. Journal of Agricultural and Food Chemistry, v. 31, no. 3, p. 476-482, 1983. https://doi.org/ 10.1021/jf00117a003

Babu, P. S.; Prabuseenivasan, P; Ignacimuthu, S. Cinnamaldehyde: A potential antidiabetic agent. Phytomedicine, v. 14, p. 15-22, 2007. https://doi.org/10.1016/j.phymed.2006.11.0 05

Bergmeyer, U. Glucose 6-phosphate dehydrogenase. In: Bergmeyer, U. Methods of enzymatic analysis. 2. ed. New York: 
Academic Press, 1984. https://doi.org/ 10.1016/B978-0-12-091302-2.X5001-4

Bopanna, K. N.; Kannan, J.; Sushma, G.; Balaraman, R.; Rathod, S. P. Antidiabetic and antihyperlipidemic effects of neem seed kernel powder on alloxan diabetic rabbits. Indian Journal of Pharmacology, v. 29, no. 3, p. 162-167, 1997.

Brandstrup, N.; Kirk, J. E.; Brunic, C. Determination of glucokinase in tissues. Journal of Gerontology, v. 12, p. 166-171, 1957.

Bürgi, W.; Briner, M.; Franken, N.; Kessler, A.C. H. One-step sandwich enzyme immunoassay for insulin using monoclonal antibodies. Clinical Biochemistry, v. 21, no. 5, p. 311-314, 1988. https://doi.org/ 10.1016/S0009-9120(88)80087-0

Caengprasath, N.; Ngamukote, S.; Makynen, K.; Adisakwattana, S. The protective effects of pomelo extract (Citrus grandis L. Osbeck) against fructose-mediated protein oxidation and glycation. EXCLI Journal, v. 12, p. 491502, 2013.

Chang, C.; Yang, M.; Wen, H.; Chern, J. Estimation of total flavonoid content in propolis by two complementary colorimetric methods. Journal of Food and Drug Analysis, v. 10, no. 2, p. 178-182, 2002.

Drabkin, D. L.; Austin, J. M. Spectrophotometric studies, spectrophotometric constants for common haemoglobin derivatives in human, dog and rabbit blood. Journal of Biological Chemistry, v. 98, p. 719-733, 1932. Available from: <http://www.jbc.org/content/98/2/719.full. pdf+html>. Accessed on: Apr. 23, 2018.

Fuhlendorff, J.; Rorsman, P.; Kofod, H.; Brand, C. L.; Rolin, B.; MacKay, P.; Shymko, R.; Carr, R. D. Stimulation of insulin release by repaglinide and glibenclamide involves both common and distinct processes. Diabetes, v. 47, no. 3, p. 345-351, 1998. https://doi.org/10.2337/diabetes.47.3.345

Gancedo, J. M.; Gancedo, C. Fructose-1,6diphosphatase, phosphofructokinase and glucose-6-phosphate dehydrogenase from fermenting and nonfermenting yeasts. Archiv für Mikrobiologie, v. 76, no. 2, p. 132-138, 1971. https://doi.org/10.1007/ BF00411787
Gao, Z.; Yin, J.; Zhang, J.; Ward, R. E.; Martin, R. J.; Lefevre, M.; Cefalu, W. T.; Ye, J. Butyrate improves insulin sensitivity and increases energy expenditure in mice. Diabetes, v. 58, no. 7, p.1509-1517, 2009. https://doi.org/ 10.2337/db08-1637

Harbourne, J. B. Phytochemical methods: A Guide to Modern Techniques of Plant Analysis. 3. en. London, UK: Chapman \& Hall Pub; 1998.

Jayanthi, M.; Sowbala, N.; Rajalakshmi, G.; Kanagavalli, U.; Sivakumar, V. Study of antihyperglycemic effect of Catharanthus roseus in alloxan induced diabetic rats. International Journal of Pharmacy and Pharmaceutical Sciences, v. 2, suppl. 4, p. 114-116, 2010. Available from: <https://innovareacademics.in/journal/ijpps /Vol2Suppl4/818.pdf>. Accessed on: Apr. 23, 2018.

Joy, K. I.; Kuttan, R. Anti-diabetic activity of Picrorriza kurroa extract. Journal of Ethnopharmacology, v. 67, no. 2, p. 143148, 1999. https://doi.org/10.1016/S03788741(98)00243-8

Kirana, H.; Srinivasan, B.P. Trichosanthes cucumerina Linn. improves glucose tolerance and tissue glycogen in non insulin dependent diabetes mellitus induced rats. Journal of Pharmacology, v. 40, no. 3, p. 103-106, 2008. https://doi.org/10.4103/0253-7613.42301

Koide, H.; Oda, T. Pathological occurrence of glucose-6-phosphatase in serum in liver diseases. Clinica Chimica Acta, v. 4, no. 4, p. 554-561, 1956. https://doi.org/10.1016/ 0009-8981(59)90165-2

Kumar, G. P.; Sudheesh, S.; Vijayalakshmi, N. R. Hypoglycaemic effect of Coccinia indica: Mechanism of action. Planta Medica, v. 59, no. 4 p. 330-332, 1993. https://doi.org/ $10.1055 / \mathrm{s}-2006-959693$

Lowry, O. H.; Rosenbrough, N. J.; Farr, A. L.; Randall, R. J. Protein measurement with the folin phenol reagent. Journal of Biological Chemistry, v. 193, p. 265-275, 1951. Available from: <http://www.jbc.org/ content/193/1/265.long>. Accessed on: Apr. 23, 2018.

McAnuff, M. A.; Omoruyi, F. O.; Morrison, E. Y.; Asemota, H. N. Changes in some liver enzymes in streptozotocin-induced diabetic rats fed sapogenin extract from Bitter yam (Dioscorea polygonoides) or commercial 
diosgenin. West Indian Medical Journal, v. 54, no.2, p. 97-101, 2005.

Meenatchi, P.; Purushothaman, A.; Maneemegalai, S. Antioxidant, antiglycation and insulinotrophic properties of Coccinia grandis (L.) in vitro: Possible role in prevention of diabetic complications. Journal of Traditional and Complementary Medicine, v. 7, no. 1, p.54-64, 2017. https://doi.org/10.1016/j.jtcme.2016.01.002

Morales, M. A.; Jabbay, A. J.; Tenenzi, H. P. Mutation affecting accumulation of glycogen. Neurospora Newsletter, v. 20, p. 24-25, 1975.

Mourya, P.; Shukla, A.; Rai, G.; Lodhi, S. Hypoglycemic and hypolipidemic effects of ethanolic and aqueous extracts from Ziziphus oenoplia (L) Mill on alloxan-induced diabetic rats. Beni-Suef University Journal of Basic and Applied Sciences, v. 6, p. 1-9, 2017. https://doi.org/10.1016/j.bjbas.2016.12.002

Mungole, A. J.; Awati, R.; Chaturvedi, A.; Zanwar, P. Preliminary phytochemical screening of Ipomoea obscura (L): A hepatoprotective medicinal plant. International Journal of PharmTech Research, v. 2, no. 4, p. 2307-2312, 2010. Available from: <http://sphinxsai.com/ Oct_dec_2010_vol2_no.4/PharmTech_vol2_no .4_1_pdf/PT=28 (2307-2312).pdf>. Accessed on: Apr. 23, 2018.

Nayak, S. S.; Pattabiraman, T. N. A new colorimetric method for the estimation of glycosylated haemoglobin. Clinica Chimica Acta, v. 109, no. 3, p. 267-274, 1981. https://doi.org/10.1016/0009-8981(81) 90312-0

Nenna, A.; Nappi, F.; Avtaar Singh, S. S.; Sutherland, F. W.; Di Domenico, F.; Chello, M.; Spadaccio, C. Pharmacologic approaches against advanced glycation end products (AGEs) in diabetic cardiovascular disease. Research in Cardiovascular Medicine, v. 4, no. 2, e26949, 2015. https://doi.org/ 10.5812/cardiovascmed.4(2)2015.26949

Pari, L.; Rajarajeswari, N. Efficacy of coumarin on hepatic key enzymes of glucose metabolism in chemical induced type 2 diabetic rats. Chemico-Biological Interactions, v. 181, no. 3, p. 292-296, 2009. https://doi.org/10.1016/j.cbi.2009.07.018

Pari, L.; Saravanan, R. Succinic acid monoethyl ester and metformin regulates carbohydrate metabolic enzymes and improves glycemic control in streptozotocinnicotinamide induced type 2 diabetic rats. Iranian Journal of Pharmacology and Therapeutics, v. 4, p. 132-137, 2005. Available from: <http://ijpt.iums.ac.ir/ article-1-57-en.pdf>. Accessed on: Apr. 23, 2018.

Ramesh, B.; Saravanan, B. R.; Pugalendi, K. V. Influence of sesame oil on blood glucose, lipid peroxidation and antioxidant status in streptozotocin diabetic rats. Journal of Medicinal Food, v. 8, no. 3, p. 377-381, 2005. https://doi.org/10.1089/jmf.2005.8.377

Shulman, G. I. Cellular mechanisms of insulin resistance. The Journal of Clinical Investigation, v. 106, p.171-176, 2000. https://doi.org/10.1172/JCI10583

Singh, J.; Kakkar, P. Antihyperglycemic and antioxidant effect of Berberis aristata root extract and its role in regulating carbohydrate metabolism in diabetic rats. Journal Ethnopharmacology, v. 123, no. 1, p. 22-26, 2009. https://doi.org/10.1016/ j.jep.2009.02.038

Singleton, V. L.; Orthofer, R.; LamuelaRaventos, R. M. Analysis of total phenols and other oxidation substrates and antioxidants by means of Folin-Ciocalteu reagent. In: Packer, L. (Ed.). Methods in enzymology: Oxidant and antioxidants (Part A). San Diego, CA: Academic Press, 1999. p. 152-178.

Sirag, H. M. Biochemical and hematological studies for the protective effect of oyster mushroom (Pleurotus ostreatus) against glycerol-induced acute renal failure in rats. Journal of Biological Sciences, v. 9, p. 746752, 2009. https://doi.org/10.3923/jbs. 2009.746.752

Smith, J. G.; Yokoyama, W. H.; German, J. B. Butyric acid from the diet: Actions at the level of gene expression. Critical Reviews in Food Science and Nutrition, v. 38, p. 259297, 1998. https://doi.org/10.1080/104086 99891274200

Sofowora, A. Medicinal plants and traditional medicine in Africa. 2. ed. Nigeria, Ibadan: Spectrum Books, 1993.

Stamp, N. Out of the quagmire of plant defense hypotheses. The Quarterly Review of Biology, v. 78, p. 23-55, 2003. 
Stefanović, O. D.; Tešić, J. D.; Čomić, L. R. Melilotus albus and Dorycnium herbaceum extracts as source of phenolic compounds and their antimicrobial, antibiofilm, and antioxidant potentials. Journal of Food and Drug Analysis, v. 23, p. 417-424 2015. https://doi.org/10.1016/j.jfda.2015.01.003

Subramanian, R.; Asmawi, M. Z.; Sadikun, A. In-vitro $\alpha$-glucosidase and $\alpha$-amylase enzyme inhibitory effects of Andrographis paniculata extract and andrographolide. Acta Biochimica Polonica, v. 55 , no. 2, p. 391398, 2008. Available from: <http://www.actabp.pl/pdf/2_2008/391.pdf >. Accessed on: Apr. 23, 2018.

Thornalley, P. J. Dicarbonyl intermediates in the maillard reaction. Annals of the New York Academy Science, v. 1043, p. 111-117, $2005 . \quad$ https://doi.org/10.1196/annals. 1333.014

Tiwari, A. K.; Rao, J. M. Diabetes mellitus and multiple therapeutic approaches of phytochemicals: Present status and future prospects. Current Science, v. 83, p. 1-10, 2002. Available from: <http://www.iisc.ernet.in/currsci/jul102002 /30.pdf>. Accessed on: Apr. 23, 2018.

Trinder, P. Determination of glucose in blood using glucose oxidase with an alternative oxygen acceptor. Annals of Clinical Biochemistry: International Journal of Laboratory Medicine, v. 6, p. 24-27, 1969. https://doi.org/10.1177/000456326900600 108

Venkateswaran, S.; Pari, L. Effect of Coccinia indica leaf extract on plasma antioxidants in Streptozotocin-induced experimental diabetes in rats. Phytotherapy Research, v. 17 , p. $605-608$, 2003. https://doi.org/ $10.1002 /$ ptr. 1195
Venkateswaran, S.; Pari, L. Effect of Coccinia indica on blood glucose, insulin and key hepatic enzymes in experimental diabetes. Pharmaceutical Biology, v. 3, p. 165-170, 2002. https://doi.org/10.1076/phbi.40.3. 165.5836

Wei, M.; Ong, L.; Smith, M. T.; Ross, F. B.; Schmid, K.; Hoey, A. J.; Burstow, D.; Brown, L. The streptozotocin-diabetic rat as a model of the chronic complications of human diabetes. Heart Lung and Circulation, v. 12, no. 1, p. 44-50, 2003. https://doi.org/10.1046/ j.1444-2892.2003.00160.x

Welihinda, J.; Karunanayake, E. H.; Sheriff, M. H.; Jayasinghe, K. S. The effect of Momordica charantia on the glucose tolerance in maturity onset diabetes. Journal of Ethnopharmacology, v. 17, no. 3, p. 277282, 1986. https://doi.org/10.1016/03788741(86)90116-9

WHO - World Health Organization. Global report on diabetes. 1 . Diabetes Mellitus epidemiology. 2. Diabetes Mellitus prevention and control. 3. Diabetes, gestational. 4. Chronic disease. 5. Public health. Geneva: WHO, 2016.

Wild, S.; Roglic, G.; Green, A.; Sicree, R.; King, H. Global prevalence of diabetes: Estimates for the year 2000 and projections for 2030. Diabetes Care, v. 27, no. 5, p. 1047-1053, 2004. https://doi.org/10.2337/diacare.27. 5.1047 